\title{
IDENTIFYING THE PROMOTION TECHNIQUES USED IN HOTELS IN BRASOV
}

\author{
Nicolae Claudiu Ochenatu ${ }^{1}$ \\ Diana Foris ${ }^{2}$
}

\begin{abstract}
This research project aims at identifying promotion techniques in the hospitality industry. It consists of identifying existing promotional techniques and finding new promotion techniques from hotel managers using the interviewing method as a research method. Over time, some hotel promotion techniques have been used to attract tourists, and these techniques have been used depending on the hotel's classification category, depending on the target market to which it is targeting, and the budget allocated to promote the hotel product. Therefore, in this research project, we will analyze the most applicable, cost-effective promotional techniques used by the managers or representatives of the hotels in Braşov through a semistructured interview made up of several questions to which interviewees will respond freely and precisely. In this project were identified the basic aspects of the research topic, the questions that come to respond to what was to be determined by the research, as well as the objectives subsequently identified. The results of the promotional actions adopted by the Braşov hotels aim to attract new customers and keep old ones, addressing directly to target customer categories as well as to the travel agency network. Also, the general public is not neglected. As a general conclusion on sales promotion techniques used in Braşov hotels, following the arguments put forward, it can be deduced that the categories of customers with income from the environment to the highest are considered for the most part but are not left apart from those with lower incomes.
\end{abstract}

Key words: promotion techniques, interviewing method, customers

\footnotetext{
${ }^{1}$ Professor, Faculty of Food and Tourism, Transilvania University of Brasov, nicusor.ochenatu@gmail.com

${ }^{2}$ Professor, Faculty of Food and Tourism, Transilvania University of Brasov, diana.foris@unitbv.ro
} 


\section{INTRODUCTION}

According to S. Medlik and H. Ingram, from the point of view of the users of hotel products, a hotel is an accomodation institution that offers facilities and services for sale, individually or grouped in various combinations. The hotel product is a component part of the tourist product and can be described as a complex assembly that includes: the material part (represented by the construction and arrangement of the hotel); the immaterial part (the service provided to the client, mainly accommodation and meals) (Medlik, Ingram, 2000).

The hotel activity presents a number of characteristics that give it specificity and which represent as many restrictions for the organization of work, as well as major constraints for those working in this field (Lupu, 2003).

According to Anastasiei, the basic components of the hotel products are the following:

- the basic services: for a hotel - the accommodation, for a restaurant - the food;

- the main peripheral services: in the case of a hotel - the culinary production, and in the case of a restaurant - a billiard room;

- secondary peripheral services: telephone, TV, bar, tennis court, swimming pool, etc.

The analysis of the hotel product is a complex activity, which involves the analysis of the aspects that characterize a hotel, as well as the analysis of the environment, of its surroundings (Anastasiei, 2004).

The presence of the own food service raises particular problems in relation to its location and functionality, which should not affect the good performance of the other activities. The food service fulfills a basic function, but it is not mandatory in all the accommodation objectives. Where it is present, this service implies the existence of a variety of compartments and types of units that will satisfy, for all tourists and at all times, both the need for food and leisure (Draica, 2003).

According to Andrei, R., Copeţchi, M. and Dragnea, L., the complementary services complete the basic services of the hotel, answering some needs related to the accommodation, but also to specific preferences for each client. Some of the additional services are compulsory depending on the classification category, being free or paid. The multitude and diversity of the available additional services is an important factor in attracting and retaining the customer. (Andrei, Copeţchi, Dragnea, 2006).

In order to know the social - economic environment, we analyze: the geographical context (for example, the location of the hotel in relation to the city, the railway, air 
connections, maritime links, etc.); the demographic context (the active population and the distribution on the three sectors: primary, secondary and tertiary); economic context (labor market and its evolution, industrial structure, etc.); the tourist context (museums, monuments, events and events, etc.) (Niţă, Butnaru, 2008).

Hotel information aims to identify strengths and weaknesses, thus highlighting the exclusive advantages of selling your own product. Reference is made to the following:

$>$ the interior and exterior appearance of the hotel (modern, clean, old, well maintained, etc.);

$>$ the atmosphere in the hotel (quiet, luxurious, commercial);

$>$ external and internal signaling;

$>$ location of the hotel (city center, periphery, tourist area, etc.);

$>$ the capacity to receive the hotel expressed in number of rooms, number of persons, number of places in the restaurant;

$>$ area of influence of the hotel (local, regional, national);

$>$ recreational options (sauna, jacuzzi).

Instances of prices in the tourism industry: price, for all material and immaterial components of a tourism product; tariff, for the tourist services offered or bought (accommodation, for example); tax, for the acquisition of a right (parking, purchase); commission, for the sales agent of the tourist products; salary, for the work performed by tourism employees; fee, for various forms of assistance (legal, medical) granted to tourists; rent, in order to benefit from a right of use (ski equipment, rented car); interest (for accessed loans) and so on. Although the notion of price also includes the notion of tariff, most often when talking about prices, it is considered the monetary expression of the value of some material goods, offered by a restaurant within a hotel), and when the term tariff is used, it is considered the value (objective or subjective) of an immaterial good, of a service (for example, the rates displayed at the reception of a hotel) (Sabo - Bucur, 2006).

\section{Promotion techniques used by hotels}

As in any other field, the promotional mix in the tourism / hotel industry is made up of five main instruments: advertising (direct advertising), public relations, personal selling and sales promotion. Tourist advertising is an impersonal and paid form of communication with the market, which aims to create and maintain the client by informing, encouraging and convincing the person about the opportunity to buy 
tourism products from the company that supports the ad. Depending on the information vehicle, we can speak of three major forms of advertising: mass media advertising (print media, radio, television); outdoor advertising (advertising panels they are very large and are located in crowded city areas or along the highways - and vehicle advertising (on the one hand, it helps to spread the message faster, but on the other hand the time for receiving the message is very short); direct advertising (also called direct marketing, is carried out either through direct contact with the client either at salons, exhibitions, or by fax, telephone, post or computer). Direct marketing is not just a simple distribution technique or means of communication/promotion of the company, but a complex variable, which involves the product (choosing one), the price (making the offer), the distribution (direct), the communication (personalized) (Olaru, 2006).

A hotel must choose "a way of promotion according to the objectives it considers, but also according to the criteria of effectiveness, the characteristics of the market in which it is located" (Barma, 2004).

In Kotler's opinion, Ph. \& Lee, N., "The decisions regarding the distribution concern the place where the customers are offered their own offer and the means by which citizens can access it" (Kotler, Lee, 2008).

In the market economy, a good tourism product, an adequate distribution channel, and an appropriate price are not enough to ensure its sale. A fourth force is needed, capable of influencing the purchasing and consumption behavior of potential customers, respectively the tourism promotion. For this reason, the tourism companies must reserve the promotion an important place in the development of their activity and harmonize the promotional efforts with the efforts undertaken for the other (classic) variables of the mix of marketing-product, price, distribution (Sabo - Bucur, 2006).

The promotional activities in tourism, as in other sectors, are aimed at attracting new customers and retaining old ones, addressing directly or through intermediaries, either to the whole public or to a certain well determined category of target customers. Within the hotel services, the promotion is characterized by a series of elements and a set of specific objectives, strategies and tools. These include: advertising, direct advertising, public relations, personal selling and sales promotion, etc. A hotel, as a service provider, wants first and foremost to become more attractive in the eyes of its customers, offering the most complex and satisfactory services, starting from ensuring a quick access to reservations (online, by telephone, at the reception)., the eventual insurance of the transport to and from the hotel of the clients, the security of the customer data, maximum comfort conditions and protocols, other facilities, as innovative as possible, like the Hotel Service, whose main objective is to satisfy the wishes and needs of the clients, represents a complex set, which implies the use of a 
large number of functions related to the different categories of services (Glăvan, 2000).

In this context, there is a need to know the existing promotion techniques used by hotels, in order to identify and implement new techniques in the future. A good understanding of this topic can bring real benefits to the development of the hotel industry.

\section{METHODOLOGY}

Considering the research thema, namely the identification of the promotion techniques used in hotels, the qualitative research was used having as a method of research the interview and, starting from the analysis of the specialized literature, the objectives that guided the research approach were formulated (found in Table 1.) The research investigates how hotels are promoted through the techniques they use, how they attract their customers and how they sell their products through marketing techniques. The main objectives refer to the identification of the promotion techniques used by the hotels in Brasov, one of the most important and well-known tourist destinations in Romania. In this study it was used the in-depth interview. This method was chosen because the interviewees were relaxed, able to speak freely without feeling constrained.

The method consists of interviewing a number of people in order to find out their personal opinion on a particular topic. In the case of this study, a number of 3 people will be interviewed, who are specialists in the hotel industry, having the function of general manager of the hotel that they run.

Table 1 shows the basic aspects of the research theme, the questions that come to answer what was proposed to be found after the research, as well as the objectives identified for carrying out this study

Table 1. The main objectives of qualitative research

\begin{tabular}{|c|c|c|}
\hline $\begin{array}{c}\text { Basic aspects of } \\
\text { marketing and } \\
\text { management }\end{array}$ & Researcher's questions & Research objectives \\
\hline $\begin{array}{c}\text { 1. Identify the connection } \\
\text { between the type of hotel } \\
\text { and the way in which it is } \\
\text { promoted. }\end{array}$ & $\begin{array}{c}\text { 1. What kind of promotion } \\
\text { techniques are used depending } \\
\text { on the price reduction? } \\
\text { 2. Which are these reductions } \\
\text { and how are they applied? }\end{array}$ & $\begin{array}{c}\text { 1. The identification of } \\
\text { the promotion techniques } \\
\text { applied to the reduction } \\
\text { of prices. }\end{array}$ \\
$\begin{array}{c}\text { 2. The identification of } \\
\text { the persons who benefit } \\
\text { from these discounts. }\end{array}$ \\
\hline
\end{tabular}




\begin{tabular}{|c|c|c|}
\hline $\begin{array}{c}\text { 2. Identification of } \\
\text { preferences in Brasov } \\
\text { hotels for smart or classic } \\
\text { techniques. }\end{array}$ & $\begin{array}{l}\text { 1. Which of the techniques } \\
\text { regarding hotel gratuities are } \\
\text { used? } \\
\text { 2. Which are the free offers } \\
\text { and to whom are they } \\
\text { addressed? }\end{array}$ & $\begin{array}{l}\text { 1. The identification of } \\
\text { the techniques that are } \\
\text { used in certain free or } \\
\text { promotional services. } \\
\text { 2. Identifying the } \\
\text { gratuities and the persons } \\
\text { who benefit from them. }\end{array}$ \\
\hline $\begin{array}{l}\text { 3. The identification of the } \\
\text { promotion techniques } \\
\text { based on the sale of tourist } \\
\text { packages. }\end{array}$ & $\begin{array}{l}\text { 1. How do the hotels sell their } \\
\text { products and services? }\end{array}$ & $\begin{array}{l}\text { 1. The identification of } \\
\text { the offers and the } \\
\text { facilities offered to } \\
\text { tourists by hoteliers and } \\
\text { travel agents. }\end{array}$ \\
\hline
\end{tabular}

The persons who constituted the research sample were chosen from a sphere of activity of interest for the present research, they are directors of three hotels in Brasov. The hotel selection criteria were based on the following: to be classified in the 3 star classification category (over $80 \%$ of the hotels operating in Brasov are classified in the 3 star category), the location and the market segment to which they are addressed. Braşov, a tourist destination located in the center of the country, in a mountainous area, is aimed especially at business tourism and relaxation tourism.

The following hotels were selected: Hotel Brilliant $3 *$ - which is located in a quiet area near the civic center of the city, focused on the business tourism; Hotel Coroana Braşovului $3 *$ - located in the historical center of the city, a quiet area with an architecture still retains the air of 100 years ago, focused on the a family tourism travelling for leisure; Hotel Armatti $3 *$ - located in the central area of the city, is aimed at business tourism, but also at tourists who come to recreate and spend their free time.An interview guide was prepared for the optimal conduct of the research. In it, the topic and purpose of the research, the research subjects and the duration of the research were mentioned. The questions/topics of discussion of the research are also noted. The interview has 8 questions.

\section{RESULTS AND DISCUSSIONS}

All the answers received from the interviewees were recorded in a database. The analysis of these answers was performed according to the database in a horizontal plane. This was done because it is desired to obtain a broad view on the main theme of the research. In order to present the relevant information in a structured way, the results are grouped on the main objectives of the research. 
Objective 1. The identification of the promotion techniques applied to the reduction of prices.

1. Which are the used promotion techniques?

$90 \%$ of the interviewees answered in the following way.

> Answer: The promotion techniques used are free offers, price reductions, seasonal and extra season offers to all hotel guests.

2. What kind of promotion techniques are used to apply the price reduction?

The answers of the interviewees were as follows:

$>$ Answer: There are some price reductions for tourists such as: restaurant price reductions for customers that have a hotel accommodation, price reductions for the first trip made through a travel agency, extra-season tariff reductions, price reductions for customers who purchase tickets at least 60 days before the start of the season, reducing the overall price of a separate service package, compared to that resulting from the sum of the individual service charges and other services.

Objective 2. The identification of the techniques that are used in certain free or promotional services.

What are the free offers and who benefits from them?

Two of the interviewees replied:

Answer: some free of charge facilities for families with children, consisting of the exemption from payment, (sometimes only for accommodation and transport services, sometimes for meals), for one or more children, free of charge such as "two nights of accommodation at the rate of one single nights "variant of the weekend rate in cities, during periods of low demand or granting a free week to tourists who buy a week or two of stay,

$>$ free of charge facilities offered by the restaurant to a customer which could be a rose, an aperitif, offering a product for the 100th buyer for free.

One of the three interviewees responds:

Answer: free hotel-airport transfers for tourists on their own who have stayed in the hotel unit, free airport transfers for passengers using some airline companies, free subscriptions for mountain cable transport to tourists which purchase tourism products suitable for winter holidays through certain travel agencies. 
$>$ Free courses offerings for sports such as: mountaineering, skiing, skating, swimming, paragliding, river rafting, for the benefit of children from families who have bought holiday packages through travel agencies specialized for such activities.

\section{How do hotels sell their products and services?}

Based on the three interviewees, we obtained the answers.

Answer: In the practice of the tour operators we find different variants of tariff reductions depending on the number and length of the periods for which they are granted, the relative level of reductions and their correlation with another category of facilities. Special offers consisting of tariff reductions during the course of events such as: championships, festivals or for certain categories of clients such as: students, students, union members, pensioners, etc. Practicing a regressive tariff, such as, the number of kilometers of travel, days of accommodation, offering hospitality checks that allow to obtain reductions in accommodation rates and meal services in the provider units with which the travel agencies have signed special contracts for this purpose.

Objective 3. The identification of the offers and facilities offered to tourists by hoteliers.

5. What are the offers and facilities offered to tourists?

Following the interviewees, the answers to this question were:

Answer: Incentive rates for promoting a future business, often given to group leaders, conference planners, business meetings, tour operators and other such persons capable of providing the hotel with a substantial income.

$>$ Answer: Preferential rates offered on weekends by the accommodation units whose regular customers, during the week, are represented by the businessmen.

$>$ Answer: Preferential rates offered by the reception structures, which aim to stimulate the extension of stays or to offer an additional free stay, for tourists who buy tourist products in the extraseasonal stays.

The results lead to the conclusion that the objectives of this research have been achieved, the promotion techniques used in hotels in Brasov are techniques that, through the promoted offer, facilitate the wishes of tourists. 


\section{CONCLUSION}

The promotional actions taken by the hotels in Brasov are aimed at attracting new customers as well as retaining the old ones, addressing directly to categories of target customers, as well as to the network of travel agencies. Nor is the general public neglected. The promotion of hotel sales through special offers or discounts is intended to stimulate an immediate or strong response from the market. By means of the technique of reducing prices and rates at the hotel level it is intended to determine the potential customers to make a first purchase, butalso to influence the occasional tourists to return to the same hotel as well as to increase the sales volume, addressing the loyal customers.

As a general conclusion about the sales promotion techniques used in hotels in Brasov, tourists benefit from price reductions, discounted rates in the off-season, free offers for families with children, free courses offerings for sports such as: mountaineering, skiing, skating, swimming and more.

The results of this research can be useful for the management of the hotel units for improving the techniques of promoting the products and services.

From an academic point of view, this study contributes to consolidating existing studies on how hotels are promoted through the techniques used, how they attract their customers and how they sell their products through marketing techniques and lays the foundations for future research.

Further research could be extended to complement this study by including more detailed qualitative studies, on a larger sample and by investigating the presence of other variables.

\section{REFERENCES}

1. Anastasiei, B. (2004). Tourism Marketing. Iaşi: Tehnopress.

2. Andrei, R., Copeţchi, M., Dragnea, L. (2006). Manual of operational techniques in the tourism activity. București: Irecson.

3. Balaure, V., Cătoiu, I., Vegheş C. (2005). Tourism marketing. Bucureşti: Uranus.

4. Barma, J. L. (2004). Marketing Tourism and Hospitality, third edition. Paris: Edition d'Organisation.

5. Draica, C. (2003). Practices of elaboration and distribution of the tourist product. Bucureşti: All Beck . 
6. Glăvan, V. (2000). Tourism in Romania. Bucureşti: Ed. Economică.

7. Kotler, Ph., Lee, N. (2008). Marketing in the public sector. Bucureşti: Metero Press.

8. Lupu, N. (2003). The hotel - economy and management. Bucureşti: All Beck.

9. Medlik, S., Ingram, H. (2000). The business of hotels, 4th edition. Oxford: Butterworth Heinemann.

10. Niţă, V., Butnaru, G. (2008). Hotel management. Iaşi: Tehnopress.

11. Sabo - Bucur, M. (2006). Tourism marketing. Bucureşti: Ed. Irecson.

12. Zaiţ, A., Anton, O. C., Olaru, O. (2006). Direct Marketing. Iaşi: Ed. SedconLibris. 